\title{
A STUDY OF THE TYPE OF INFANTILISM IN HOOKWORM DISEASE**
}

\author{
ISAAC: IVAN LEMANX, M.D.
}

NEW ORLEAXS

A search of the literature has shown that no one has yet given more than cursory notice to the striking infantilism of hookworm disease. So striking is the phenomenon that authorities have contented themselves with mentioning its existence as a well-known fact. The subject is dismissed with the general statement that hookworm victims are undersizerl, lack pubic and axillary hair and show other eridences of lack of development.

It is the purpose of this paper to report in detail the exact study of the grade of development in a case of hookworm disease and, by contrasting it with other types of infantilism, to endeavor to fix its classification.

Personal History.-0. J., a white male, aged 22, from Biloxi, Mississippi, was admitted to the Charity Hospital, April, 1909, for treatment for anemia secondary to hookworm infection. He had ground-itch for the first time when he was 6 years old and had it every summer until he stopped going barefont at the age of 19. He has not grown since he was 12 years old. From his tenth year he used to "bloat up" and did not feel like going about. This lasted for five or six years, but from his sixteenth year he has been pretty well except that he tired easily. He attended school off and on from the time he was 5 years old-altogether for perhaps three years. When he left seliool at 14 he was in the seventh grade. He had no difficulty with his lessons and always stood near the top of a class of from ten to twenty-five. At 17 he was sick a whole summer with fever, which was diagnosed as malaria. He had measles at 14 and mumps at 21 . The diagnosis of uncinariasis was made by a physician who was called to see him because of a slight cold. He was first treated at the Touro Infirmary in November, 1907 , and felt a great deal better after his treatment there. He returns now for treatment because he fatigues easily. He las lived at various times in the following places (all in Mississippi): J3iloxi, Pass (Christian, Orrisburg, Poplarville, Hattiesbure.

framily History. - The father died of typhoid. but the mother is living and well. One brother is living and well, 20 years old, weighs 160 pounds; he has had ground-itch a few times. Two sisters, 17 and 20 rears old, respectively, are living and well. Each weighs 115 pounds. Neither has had ground-itch. The patient says that his brothers and sisters are well developed.

Present condition.-The patient is a small, pale, sallow individual, apparently about 13 or 14 years old. His intelligence is good. His answers are quick, his skin is dry, his hair is thick and coarse and there are areas of alopecia over the occiput.

\footnotetext{
*From the Clinic of Prof. George Dock, Tulane Lniversity of Louisiana.
} 
Thorax: Heart not enlarged; no murmurs. Lungs normal.

Abdomen: No distention. Liver is not enlarged.

Spleen is not palpable. Slight tenderness on pressure over the epigastrium.

Wing scapula.

No axillary or pubic hair.

Genitalia correspond in size and development to apparent age of patient.

The following blood-picture (made May 10, 1909) is representative of a number of blood examinations made from time to time:

Hemoglobin, 45 per cent.; red blood cells, 4,160,000 to the c.mm.; leucocytes, 7,600 to the c.mm. Eosinophils, $9 \% 3$ per cent.

Examination of stools showed ova of uncinaria still present.

Measurements:

Skull:

Fronto-oceipital circumference, $53.5 \mathrm{~cm}$.

Mento-vertical circumference, $5 \bar{r} \mathrm{~cm}$.

Mento-occipital circumference, $61 \mathrm{~cm}$.

Chest :

Full inspiration (at nipple level), $70.25 \mathrm{~cm}$.

Full expiration (at nipple level), $63.75 \mathrm{~cm}$.

Full inspiration (at level of armpits), $63.5 \mathrm{~cm}$.

Full expiration (at level of armpits), $58.5 \mathrm{~cm}$.

Full inspiration (at base of chest), $64.75 \mathrm{~cm}$.

Full expiration (at 8 th rib), $58 \mathrm{~cm}$.

Height standing, $139.5 \mathrm{~cm}$.

Distance from umbilicus to the ground, $85 \mathrm{~cm}$.

Distance from the tip of his fingers (placed on his thigh while standing) to the ground, $54.5 \mathrm{~cm}$.

Upper extremity :

Acromion to olecranon, left, $27.5 \mathrm{~cm}$; right, $27 \mathrm{~cm}$.

Olecranon to tip of middle finger, left, $37 \mathrm{~cm}$; right, $37.25 \mathrm{~cm}$.

Ulna, left, $22 \mathrm{~cm}$; right, $22 \mathrm{~cm}$.

Hands :

Thumb (right) metacarpal, $5 \mathrm{~cm}$; first phalanx, $2 \mathrm{~cm}$. ; second phalanx, $2.5 \mathrm{~cm}$. ; (left) metacarpal, $5 \mathrm{~cm}$. ; first phalanx, $2.5 \mathrm{~cm}$; second pha. lanx, $2 \mathrm{~cm}$.

First finger (right) metacarpal, $7 \mathrm{~cm}$; first phalanx, $3.25 \mathrm{~cm}$; second phalanx, $2.5 \mathrm{~cm}$; third phalanx, $1.5 \mathrm{~cm}$.; (left) metacarpal, $7 \mathrm{~cm}$.; first phalanx, $3.5 \mathrm{~cm}$; second phalanx, $2.5 \mathrm{~cm}$; third phalanx, $1.5 \mathrm{~cm}$.

Second finger (right) metacarpal, $7 \mathrm{~cm}$; first phalanx $4 \mathrm{~cm}$.; second phalanx, $3 \mathrm{~cm}$.; third phalanx, $1.5 \mathrm{~cm}$; (left) metacarpal, $7 \mathrm{~cm}$.; first phalanx, $3.5 \mathrm{~cm}$; second phalanx, $2.5 \mathrm{~cm}$; third phalanx, $2 \mathrm{~cm}$.

Third finger (right) metacarpal, $7 \mathrm{~cm}$; first phalanx, $4 \mathrm{~cm}$; second phalanx, $2.5 \mathrm{~cm}$; third phalanx, $1.5 \mathrm{~cm}$; (left) metacarpal, $7 \mathrm{~cm}$; first phalanx, $4 \mathrm{~cm}$; 'second phalanx, $2 \mathrm{~cm}$; third phalanx, $1.5 \mathrm{~cm}$.

Fourth finger (right) metacarpal, $6 \mathrm{~cm}$.; first phalanx, $3 \mathrm{~cm}$.; second phalanx, $1.5 \mathrm{~cm}$; third phalanx, $1.5 \mathrm{~cm}$; (left) metacarpa], $6 \mathrm{~cm}$; first phalanx, $2.5 \mathrm{~cm}$; second phalanx, $1.75 \mathrm{~cm}$; third phalanx, $1.5 \mathrm{~cm}$.

Pelvis :

Circumference over crest of ilia, $56 \mathrm{~cm}$.

Circumference over great trochanters, $58 \mathrm{~cm}$. 


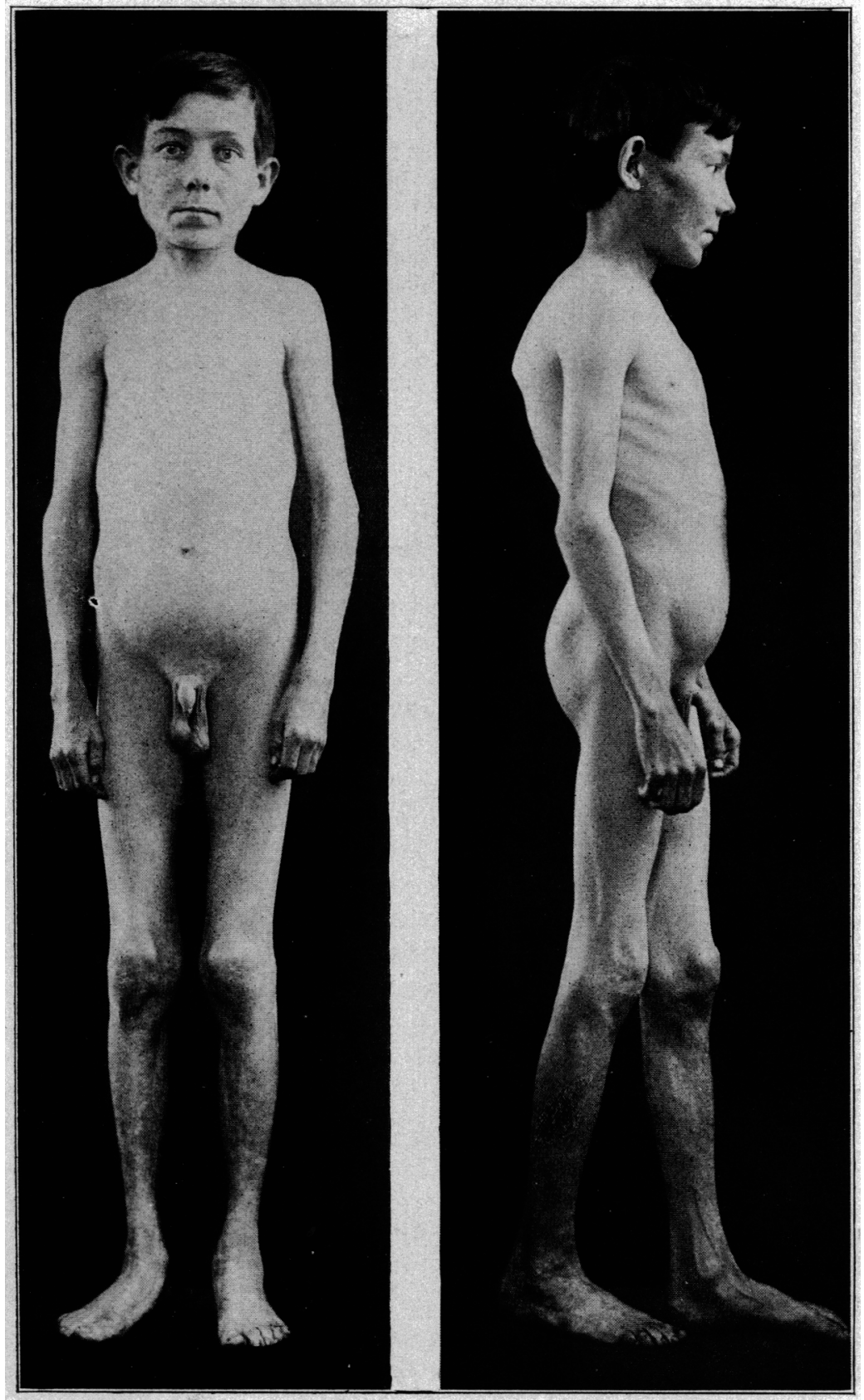

Fig. 1.--Patient affected with hookworm infantilism, front view.

Fig. 2.- Same patient as in Figure 1 , side view. 
Lower extremities:

From anterior superior spine of ilium to internal condyle, both sides, $43.5 \mathrm{~cm}$.

From anterior superior spine of ilium to external malleolus, both side;, $75.5 \mathrm{~cm}$.

Length of feet, $20.5 \mathrm{~cm}$.

It will be noticed that the dwarfing process is uniform. There is no dispriportion between the lengths of the limbs and that of the trunk, and no undue size of the extremities or of the head.

Skiagraphs of the long bones of the thorax and of the pelvis show no deformity and no abnormality of any kind. There is no bowing of the shafts of the long bones, no thickening of their ends, no evidence of almormal cartilage proc. esses in the epiphyses, no thickening of the periosteum. The ribs are apparently of uniform thickness throughout. The pelvis is symmetrical and of proper size in proportion to the rest of the skeleton.

As a standard by which we mar estimate the degree in which our patient's growth has been retarded, I have adopted the suggestion of Rotch $^{1}$ and have attempted to arrive at the anatomic age of the patient by comparing his skeleton with those of the arerage normal individual. For this purpose Rotch has used the skiagraphs of the bones of the wrist and has by a series of observations of rormal wrists fixed a standard of development for each age. The skiagraph of my patient's wrist shows seven carpal bones well dercloped, namely, the scaphoid, semilunar, cuneiform, trapezium, trapezoid, os magnum, and unciform. In addition, the lower epiphyses of both ulna and radius are well developed. The shadow of the pisiform bone is barely to be seen. A reference to Rotch's table would place this wrist in Class $K$ and cause us to estimate the true anatomic age of our patient as about 10 or 11 rears. This is the estimatr. placed by Ir. Roteh, to whom the skiagraph has been submitted. We may conclude, therefore, that hookworm infection may retard the developmental changes to such an extent as to cause an individual of 22 to retain the grade of ossification of the average normal inclividual of 10 or 11 .

The infantilism of hookworm disease has much in common with infantilism from certain other causes. On the other hand there are some forms of arrested derelopment with which it stands in strong contrast and with which it is not likely to be confused. Such types are, for example, the achondroplastic dwarf, the mongolian idiot, the rachitic dwarf. From the achondroplastic dwarf, my patient is readily distinguished by the alssence of the characteristic lack of proportion between the lengths of the extremities and that of the trunk. Besides there is no trident hand, no bowing of the long bones. no decentralization of the umbilicus. no prognathism as there usually is in achondroplasia. The genitalia share in the retardation. while in achondroplasia they correspond in size

1. Roteh, T. M.: Chronolugic and Anatomic Age in Early Life, .Jour. Am. M. Asst.. 1908. li, 1197. 


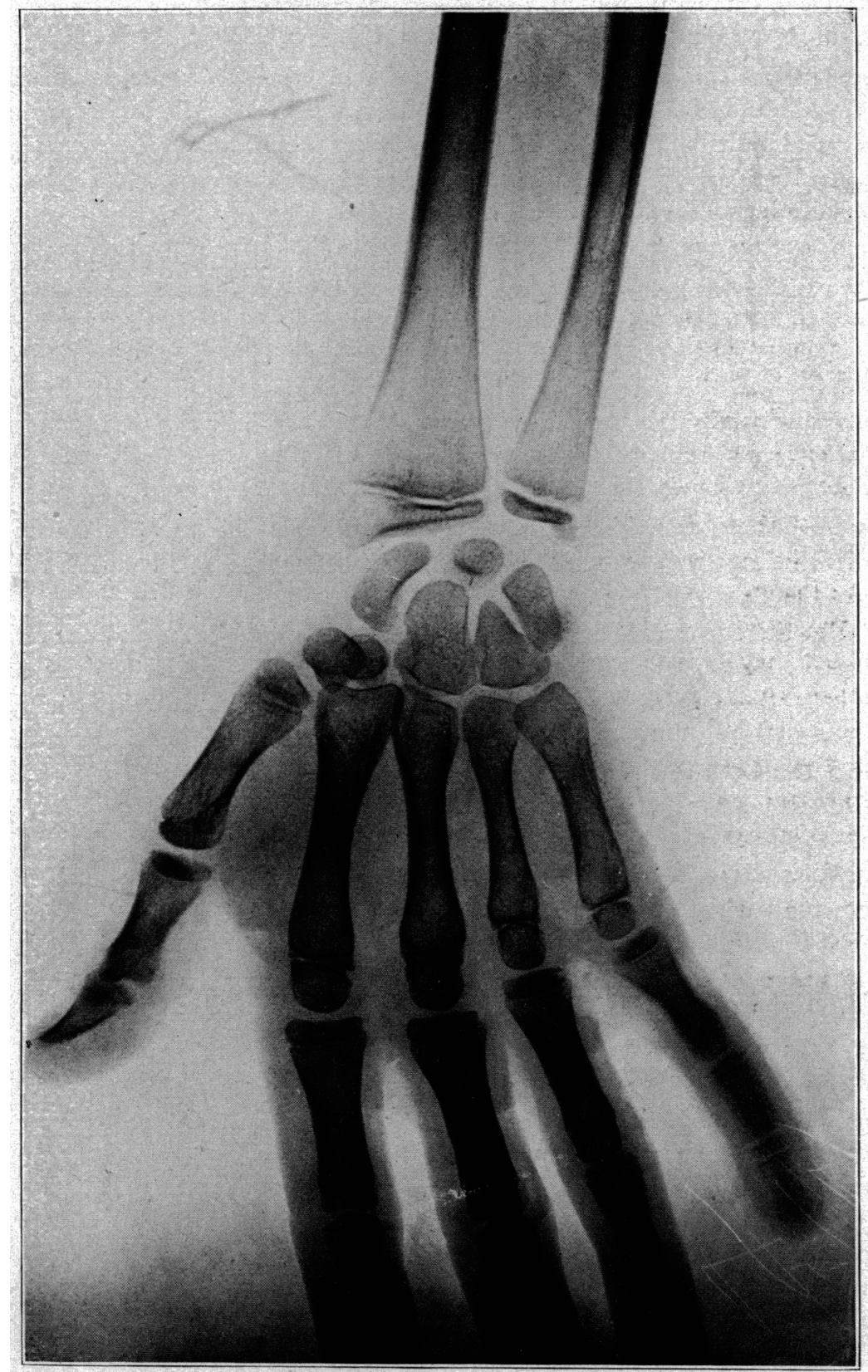

Fig. 3.-Skiagraphic view of patient's hand. 
and development to the true age of the individual. The skiagraphs of the hookworm dwarf show none of the cartilage changes of the achondroplastic. The hookworm dwarf has equally as little in common with the rachitic dwarf. In rickets the bone shadow is paler than normal and the medullary canal is larger, making the cancellous tissue smaller. Hence there is a bending and bowing of the long bones. The ends of the long bones are enlarged and there is irregular cartilaginous development of the epiphyses. In addition there is an unduly large skull, squared and frequently "bossed." None of these features are present in the hookworm dwarf.

There could be no question of the difference between the hookworm infantile and the outspoken fully developed cretin. The latter, with his thick, protruding lips, big head, short thick neck, long cylindrical torso, lumbar lordosis and infantile pelvis, his thick skin and marked adiposity, as well as his drooling idiocy, presents a picture not to be confused. If the hookworm dwarf has no mental characteristics in common with the cretin, he has equally none with the mongolian idiot. In addition, he lacks the slant-eyed mongolian facies.

But there is a masked cretin, the dysthyroid or hypothyroid infantile (type Brissaud) who may have a much closer resemblance to our patient. In both there is a simple retardation of the development in general, involving not only the skeleton but the genitals and the secondary sexual characteristics; in both there may be a dry skin with dry, harsh, scanty hair. But even the masked cretin, fairly intelligent though he may be, has usually enough of the characteristics of the cretin, namely, the round full face with thick lips, small nose and thick skin, to distinguish him from the patient of the type of ours. It may not be out of place here to repeat the suggestion often made before, that infantilism of widely differing fundamental causation may be due to disturbance of the function of the thyroid and other ductless glands with internal secretion. In this sense, therefore, hookworm infantilism may be a dysthyroid condition. After all, infantilism is only a symptom-complex, not a disease. What the actual pathologic lesion is, is still to be determined for hookworm infection as for many other causative factors; it may be thyroid, pituitary, ovarian, testicular, etc., etc. The only point I wish to make here is that the masked cretin and the hookworm infantile do not differ markedly in kind, a fact suggesting a possible relation of pathology.

The cases reported by Ettore Levi ${ }^{2}$ show that the infantilism of the type Lorain presents skeletal changes not different in kind from those in my case. The type Lorain infantile has been described as having a smail

2. Levi, Ettore: Nouv. iconog. de la Salpêtrière, 1908, xxi, 421. 


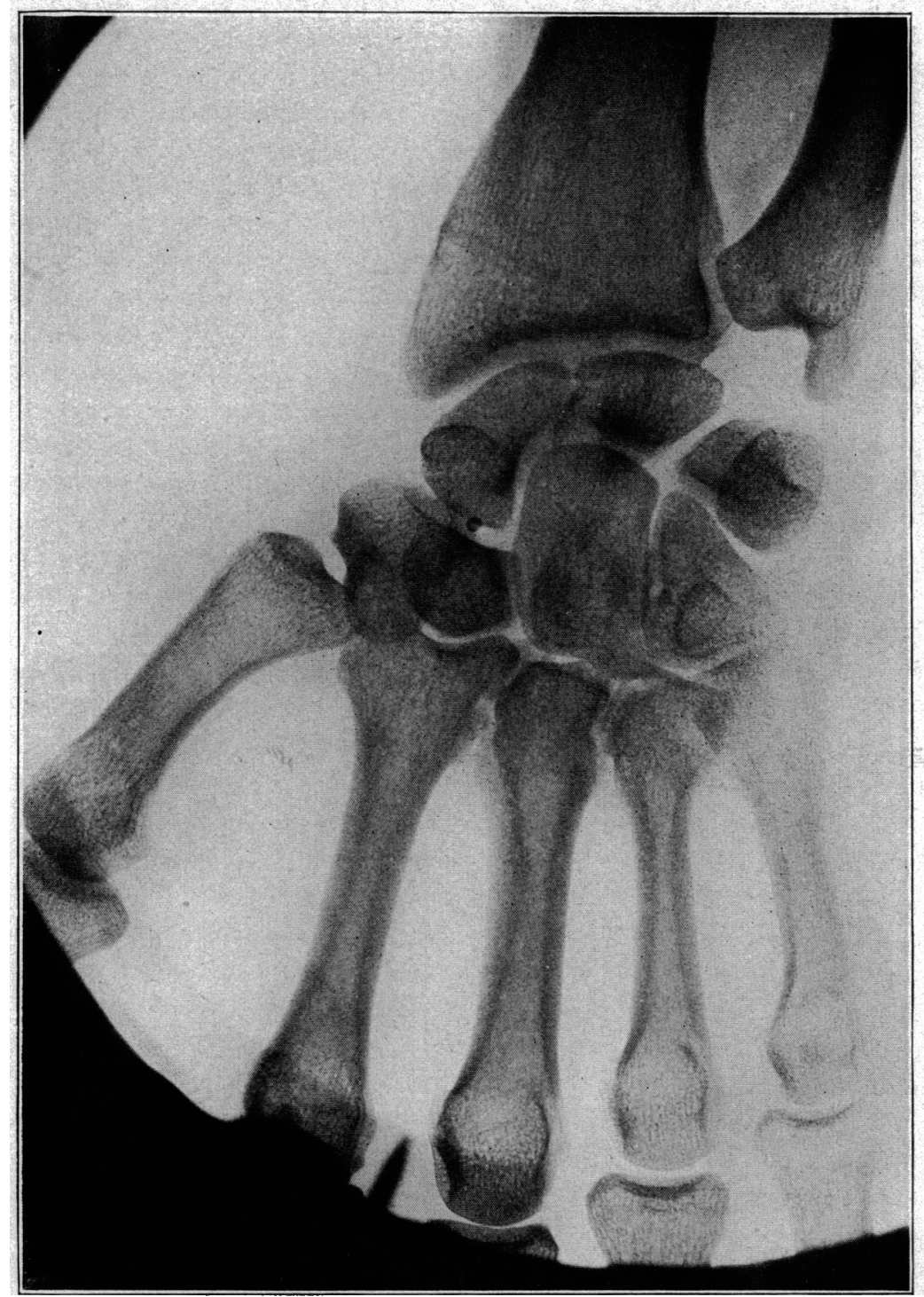

Fig. 4.-Skiagraphic view of normal adult hand for comparison. 
stature, delicate, slender skeleton and form, long, slim legs, relatively small trunk, infantile sternum and pelris, long neck with fine, pale skin. and no adipose envelop. The genitals are small and the secondary sexual characteristics are usually lacking. The dimensions of the body in general are small and the proper relation between the various parts is well preserved. An excellent example of the type is the case reported by Dr. Van Wart and myself ${ }^{3}$ in the May number of Tire Anchives of Intenal Medicine. We considered the cause of this case to be pituitary tumor, which was also a probable cause in one of Levi' (ases. But infantilism of this type is also not to be considered a distinct entity from the standpoint of etiology. On the whole our hookworm infantile conforms neither to the type Brissaud (dysthyroid or athyoid) nor to the type Lorain in his general appearance, suggesting rather the second than the first and standing midway between the two. The retarded derelopment saicl to be due to chronic malaria is probably analogous to that of hookworm infection and Levi speaks of Lancereaux and Ferranini's malarial cases as being of the Lorain type. Pellagra (hereditary) has also been held responsible for a similar form of infantilism.

I have found no skiagraphic study of infantilism of the type Lorain due to such causes as hereditary syphilis (unless Levi's are to be so regarded), tuber(ulosis (of the parents), mitral stenosis, alcohol, lear, nicotin, ete. but it seems more than probable that they would show sinply a general retardation without special changes in bone or cartilage.

I conclude, therefore, that the infantilism of hookworm disease shows in general the following characteristics:

1. A general retardation of growth. symmetrical and harmonious.

2. A simple retardation of skeletal changes.

3. A failure of development of the genitals as well as the absence of secondary sexual characteristics.

4. A mental slowness and dulness (not present in my patient).

5. A general appearince which conforms neither to the lirissaud nor the Lorain type.

602 Perrin Builıling.

3. Lemann, T. T., and Van Wart. R. M.: A Case of Infantiliom with Alsence

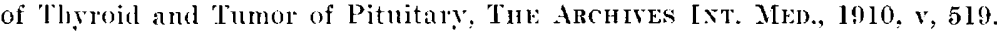

